\title{
Effects of Sandplay Therapy on Parent-Child Communication in Chinese-Korean Children Who Experienced Separation from Their Parents
}

Chung, Da Un
Mikyung Jang**

\begin{abstract}
$<$ Abstract $>$
This study performed a sandplay therapy targeting Korean-Chinese children who have ever experienced the separation with their parents to analyze its effect. 6 sessions of sandplay therapy program were conducted to 8 children residing in Yanbian Korean Autonomous Prefecture who have experienced the separation with their parents for more than one year. To verify the effectiveness, Parent-child communication scale was conducted before and after the sandplay therapy to experimental group and waiting group, each one session of parent-child inter communication was conducted before and after the program respectively for qualitative analysis, and the individual interview was conducted to parents and children after total program. As a result of this study, the communication between children who have experienced the separation with their parents and Korean-Chinese parents has been improved meaningfully, as a result of qualitative analysis, the program has brought the change in the expression and improvement awareness of children's communication. In conclusion, the sandplay therapy has brought the improvement of communication between children and parents.
\end{abstract}

Keywords : sandplay therapy, separation, communication, Korean-Chinese

* Play therapist, Hopeful Psychology Development Center (dw6426@naver.com)

** Professor, Department of Child Welfare, Namseoul University (jangmiky@hotmail.com) 
Journal of Symbols \& Sandplay Therapy, Vol.7 No.2.

\section{I . Introduction}

\section{Research Objective and Necessity}

A massive population transfer took place in China in the 1990s in the wake of the reform and opening-up policy as well as the establishment of Korea-China diplomatic ties. Particularly after the Chinese economic reform, more than half of the Korean-Chinese population immigrated to major cities in China, South Korea, or other foreign countries (Kang, 2012; Koo, 2011). And since the South Korean government began issuing a five-year employment pass for overseas Koreans in 2007, the number of Korean-Chinese coming to Korea has risen rapidly (Woo \& Lee, 2013; Kim, 2009). Statistics as of July 31, 2015 showed that among $1,801,401$ foreigners residing in Korea, more than $30 \%$ or 623,432 of them were Korean-Chinese (Korea Immigration Service, 2015). Due to the rise of overseas immigration, over 30,000 Korean-Chinese children and adolescents in the Yanbian Korean Autonomous Prefecture alone do not live with their mother, father, or both. This figure accounts for a staggering 50\% of all children and adolescents in the area (Lee, 2014; Yanbian Daily, 2011). A survey on Korean-Chinese students in Heilongiiang Province also disclosed that 540 or 73.5\% of middle and high school students in the region do not live with their parents. The primary reason for the separation was economic issue, accounting for $78 \%$ of the total response (Ahn, 2009).

Frequent overseas immigration by the parents renders family structure vulnerable and intra-family relationship unstable (Jeong, 2016). The rise in the number of families experiencing parent-child separation increases developmental-psychological and social concerns, in terms of positive development, adaptation, and parent-child relationship (Jo \& Lee, 2005).

Positive communication enables one to form good relationships and carry out his or her social activities. Positive communication makes use of not only verbal elements but also nonverbal elements, which include facial expressions, eye contact, gestures, bodily motions, postures, looks, and physical distance (Lee, 2009; Lee, et al., 2006). In other words, communication helps create and maintain close relationships by utilizing all verbal and 
nonverbal elements. It is a basic and essential process of interaction through which attachment and connectedness are felt (Jeong, 2016). In early life, communication is learned through relationships with parents and family members. Parent-child communication is essential for child's social adjustment, inter-family communication and relationships serve as a basic framework for all life experiences.

Studies conducted in both China and Korea have confirmed that a family environment in which at least one of the parents is absent has a negative impact on the child's cognitive and socio-emotional developments (Jo \& Lee, 2005; Kim, 2004; Lee \& Lee, 2004). Parents' moving abroad generates emotional instability and behavior problems on the part of the child. Instability in the family structure and lowered quality of familial relationship cause the child left behind to experience school maladjustment problems and psychological disorders and to become involved with delinquent activities (Yoon, et al., 2012; Jeong, et al., 2011; Park \& Park, 2005). Some of the behavior problems manifested by children and adolescents in Yanbian were runaway, skipping school, extreme loneliness, poor academic performance, and internet addiction (Kim, et al., 2012).

This study therefore aimed to make a therapeutic approach, through sandplay therapy, to the difficulties experienced in parent-child communication and interaction by these Korean-Chinese children.

While there exist a range of psychological approaches that have positive effects on parent-child relationships, sandplay therapy was chosen in view of the child participants' unique situation: that they are Korean-Chinese children living in China. Because no attempts have been made to employ sandplay therapy for Korean-Chinese children who experienced separation from their parents, this study sought to supplement the limitations in previous psychotherapy-related researches. After meeting and observing the participants residing in the city of Yanbian, children who had been separated from their parents for a year or more and faced difficulties in parent-child communication were selected. These children were given a protected space called sandplay therapy, in which they could express themselves. Sandplay therapy is a process of inner dialogue on the part of the client, during which the client expresses his or her experiences through nonverbal symbols such as sand, water, the body, and figures (Lee \& Shahi, 
Journal of Symbols \& Sandplay Therapy, Vol.7 No.2.

2016). This unique attribute of sandplay therapy allows the therapist to make, even without much verbal interaction, interventions through symbols and to understand the nonverbal aspects (Lee and Jang, 2015). The basic premise of this study was that quantitative analysis alone is not sufficient to gain a full understanding of the therapeutic process. Therefore, a qualitative analysis was also conducted in order to make a comprehensive analysis.

\section{Research Questions}

The main questions of this research were as follows:

1. Can sandplay therapy improve parent-child communication of Korean-Chinese children who experienced separation from their parents?

2. What changes are brought about by sandplay therapy in parent-child communication of Korean-Chinese children who experienced separation from their parents?

\section{П. Research method}

\section{Participants}

\section{1) Selection and recruitment processes}

Participants of this research were Korean-Chinese children, aging from 10 to 13, who, at the time of the therapy, were living in the Yanbian Korean Autonomous Prefecture and had the experience of being separated from their parents. They were recruited through written letters, phone calls and emails with the help of the Social Science Research Institute at Yanbian University in the city of Yanji. Among those who volunteered, 16 children who had been separated from their parents for a year or more were selected, with 8 in the experimental group and 8 in the wait list control group. First, all 8 children in the experimental group were provided with the therapy program, after which the same program was given to the other 8 children in the wait list control group as well. 
Chung, Da Un · Jang, Mikyung / Effects of Sandplay Therapy on Parent-Child Communication in Chinese-Korean Children Who Experienced Separation from Their Parents

\section{2) Noteworthy facts and chief complaints of the participants}

Noteworthy facts and chief complaints of the 8 experimental group members are outlined in Table 1:

Table 1. Noteworthy facts and chief complaints of the experimental group

\begin{tabular}{|c|c|c|c|c|}
\hline $\begin{array}{l}\text { Parti- } \\
\text { cipant }\end{array}$ & Gender/Age & Family relations & Drawing test & Chief complaints \\
\hline A & $\begin{array}{c}\text { Male } \\
\text { /Aged } 10\end{array}$ & $\begin{array}{l}\text { - The father immigrated } \\
\text { abroad before the client } \\
\text { became a month old } \\
\text { - He lived together with his } \\
\text { maternal grandmother who } \\
\text { had Alzheimer's disease } \\
\text { - His older sister was } \\
\text { studying abroad }\end{array}$ & $\begin{array}{l}\text { While he had a desire for } \\
\text { relationship, he was anxious, } \\
\text { ostentatious and aggressive. } \\
\text { Uncertainty and helplessness were } \\
\text { observed in terms of peer relationship. } \\
\text { It appeared that there was a poor } \\
\text { family communication at home. }\end{array}$ & $\begin{array}{l}\cdot \text { Had a lot of fear } \\
\cdot \text { Behaved like a girl } \\
\text { - Tried to read other's } \\
\text { mind often }\end{array}$ \\
\hline B & $\begin{array}{c}\text { Male } \\
\text { /Aged } 11\end{array}$ & $\begin{array}{l}\text { - Parents divorced when the } \\
\text { client was } 11 \text { months old } \\
\text { - It had been } 6 \text { months } \\
\text { since he lived together } \\
\text { with his stepfather }\end{array}$ & $\begin{array}{l}\text { While he did not express himself, he } \\
\text { did have desire for relationship. In } \\
\text { reality he wss unstable, ostentatious, } \\
\text { and aggressive. On the other hand, } \\
\text { he was withdrawn and depressed. It } \\
\text { was clear that there was no effective } \\
\text { communication in the family. }\end{array}$ & $\begin{array}{l}\cdot \text { Had no respect for } \\
\text { elders } \\
\cdot \text { Self-centered } \\
\cdot \text { Stubborn } \\
\text { - Easily became irritated }\end{array}$ \\
\hline $\mathrm{C}$ & $\begin{array}{c}\text { Male } \\
\text { /Aged } 10\end{array}$ & $\begin{array}{l}\text { The mother went abroad } \\
\text { for a short period of time } \\
\text { when the client was } 6 \\
\text { - The father was busy with } \\
\text { farming and thus rarely } \\
\text { came home }\end{array}$ & $\begin{array}{l}\text { He felt discomforted with the family } \\
\text { relations and lacked the ability to } \\
\text { cope in certain situations. Withdrawal } \\
\text { and helplessness were manifested in } \\
\text { social situations. While he had } \\
\text { relationship needs, he was afraid of } \\
\text { rejection. }\end{array}$ & $\begin{array}{l}\text { - Faced difficulties in } \\
\text { making friends } \\
\text { - Had a hard time } \\
\text { completing a task } \\
\text { - Addicted to video } \\
\text { games } \\
\text { - Had a lot of anger }\end{array}$ \\
\hline $\mathrm{D}$ & $\begin{array}{c}\text { Male } \\
\text { /Aged } 13\end{array}$ & $\begin{array}{l}\text { - Both parents went abroad } \\
\text { when the client was 5-8 } \\
\text { years old } \\
\text { - Parents divorced when the } \\
\text { client was ten }\end{array}$ & $\begin{array}{l}\text { He had a need to be recognized by } \\
\text { others. He felt unsure of himself, was } \\
\text { immature in terms of inter-personal } \\
\text { interactions, and lacked the ability to } \\
\text { cope with different situations. He had } \\
\text { relationship needs but was withdrawn, } \\
\text { and wa concerned about forming } \\
\text { relationship with others. }\end{array}$ & $\begin{array}{l}\text { - Had a hard time } \\
\text { making friends } \\
\text { - Very shy } \\
\text { - Low self-esteem } \\
\text { - Became angry when } \\
\text { what he had thought } \\
\text { was wrong }\end{array}$ \\
\hline
\end{tabular}


Journal of Symbols \& Sandplay Therapy, Vol.7 No.2.

Table 1. Noteworthy facts and chief complaints of the experimental group (continued)

\begin{tabular}{|c|c|c|c|c|}
\hline $\begin{array}{l}\text { Parti- } \\
\text { cipant }\end{array}$ & Gender/Age & Family relations & Drawing test & Chief complaints \\
\hline $\mathrm{E}$ & $\begin{array}{c}\text { Female } \\
\text { /Aged } 13\end{array}$ & $\begin{array}{l}\text { - Both parents were abroad } \\
\text { when the client was } 4 \\
\text { months - } 6 \text { years old } \\
\text { - Parents divorced by } \\
\text { mutual agreement in } \\
2015\end{array}$ & $\begin{array}{l}\text { It appeared that she was experiencing } \\
\text { a family discord. She seemed to be } \\
\text { isolated internally, emotionally tense } \\
\text { and withdrawn. She also displayed } \\
\text { anxiety in terms of her interaction } \\
\text { with the environment. She was } \\
\text { disturbed by emotional stimulation, } \\
\text { passive in emotional exchanges, and } \\
\text { had a desire for affection. }\end{array}$ & $\begin{array}{l}\text { - Absence of father } \\
\text { - Poor school grades }\end{array}$ \\
\hline $\mathrm{F}$ & $\begin{array}{c}\text { Female } \\
\text { /Aged } 13\end{array}$ & $\begin{array}{l}\text { - Both parents were abroad } \\
\text { when the client was } 4 \\
\text { months - } 6 \text { years old } \\
\text { - Parents divorced by } \\
\text { mutual agreement in } 2015\end{array}$ & $\begin{array}{l}\text { She controlled herself for the sake of } \\
\text { others and had a low self-esteem. She } \\
\text { was anxious and withdrawn in social } \\
\text { situations. She was afraid of } \\
\text { expressing herself and also of } \\
\text { relationships. }\end{array}$ & $\begin{array}{l}\text { - Absence of father } \\
\text { - Detachment from the } \\
\text { mother } \\
\text { - Poor school grades }\end{array}$ \\
\hline G & $\begin{array}{c}\text { Female } \\
\text { /Aged } 11\end{array}$ & $\begin{array}{l}\text { - Both parents went abroad } \\
\text { when the client was } 5 \\
\text { years old } \\
\text { - Older sister was studying } \\
\text { abroad } \\
\text { - The client was living } \\
\text { together with both her } \\
\text { parents at the time of } \\
\text { therapy }\end{array}$ & $\begin{array}{l}\text { While she had relationship needs, she } \\
\text { lacked social skills. She wanted } \\
\text { stability, but was anxious. She was } \\
\text { highly conscious of others. }\end{array}$ & $\begin{array}{l}\cdot \text { Extreme stress } \\
\text { - Extreme leadership }\end{array}$ \\
\hline $\mathrm{H}$ & $\begin{array}{c}\text { Female } \\
\text { /Aged } 12\end{array}$ & $\begin{array}{l}\text { - Father went abroad when } \\
\text { the client was } 6 \\
\text { - Mother had a stillbirth } \\
\text { when the client was } 10 \\
\text { - The client lived together } \\
\text { with both her parents at } \\
\text { the time of therapy }\end{array}$ & $\begin{array}{l}\text { While interested in relationships, she } \\
\text { was ambivalent, had a weak ego, and } \\
\text { was possibly anxious. She was also } \\
\text { withdrawn and anxious in social } \\
\text { situations. }\end{array}$ & $\begin{array}{l}\cdot \text { Anxiety } \\
\cdot \text { Shy of strangers } \\
\cdot \text { Relationship issues }\end{array}$ \\
\hline
\end{tabular}

3) Test for socio-demographic homogeneity between the experimental group and the wait list control group

Mann-Whitney $\mathrm{U}$ test was applied to see whether the experimental group and the 
wait list control group are homogeneous in terms of their socio-demographic characteristics, the result of which is outlined in Table 2:

As can be seen from the table, no significant differences were found between the experimental group and the wait list control group, from which we can hypothesize that the two groups are homogeneous.

Table 2. Test for socio-demographic homogeneity between the experimental group and the wait list control group $(\mathrm{N}=16)$

\begin{tabular}{|c|c|c|c|c|}
\hline & & $\begin{array}{l}\text { Experimental } \\
\text { group }\end{array}$ & $\begin{array}{l}\text { Wait list } \\
\text { control group }\end{array}$ & $\mathrm{Z}$ \\
\hline & & $\mathrm{N}(\%)$ & $\mathrm{N}(\%)$ & \\
\hline \multirow{2}{*}{ Gender } & Male & $4(50)$ & $4(50)$ & \multirow{2}{*}{-1.15} \\
\hline & Female & $4(50)$ & $4(50)$ & \\
\hline \multirow{2}{*}{ Age } & Below 11 & $2(25)$ & $5(62.5)$ & \multirow{2}{*}{.00} \\
\hline & 11 or above & $6(75)$ & $3(37.5)$ & \\
\hline \multirow{2}{*}{$\begin{array}{c}\text { Current level of } \\
\text { education }\end{array}$} & Elementary school & $4(50)$ & $4(50)$ & \multirow{2}{*}{.00} \\
\hline & Middle school & $4(50)$ & $4(50)$ & \\
\hline \multirow{3}{*}{$\begin{array}{c}\text { Expected level of } \\
\text { education }\end{array}$} & Bachelor's & $3(37.5)$ & $2(25)$ & \multirow{3}{*}{-.55} \\
\hline & Master's and above & $3(37.5)$ & $4(50)$ & \\
\hline & Study abroad & $2(25)$ & $2(25)$ & \\
\hline \multirow{2}{*}{ Time of conversation } & Less than an hour & $3(37.5)$ & $3(37.5)$ & \multirow{2}{*}{-1.22} \\
\hline & An hour or more & $5(62.5)$ & $5(62.5)$ & \\
\hline
\end{tabular}

\section{Tools}

To measure changes in parent-child communication as perceived by the child, this study administered an adapted version of Barnes and Olson's (1982) Parent-Adolescent Communication Scale (PACS) which was used in the study of Kim (1989). PACS consists of 20 items-10 on functional communication and 10 on dysfunctional communication-measuring the quality of communication between child and parent. Items of functional communication, as 
Journal of Symbols \& Sandplay Therapy, Vol.7 No.2.

perceived by the child, measure the positive aspects of parent-child communication in which the child has no problem in communicating with the parent, do not feel repressed in the process of interaction, and can freely express his or her thoughts. On the other hand, the dysfunctional communication subscale contains items that measure the negative aspects of parent-child communication in which the child faces trouble in communicating and experiences negative interaction with the parent. Items are rated on a 5-point scale, from "strongly disagree" to "strongly agree." Reverse scoring is applied for dysfunctional communication items. Scores can range from 20 to 100. Higher scores represent positive, open and functional parent-child communication. Cronbach's alpha of PACS was .72. The structure of PACS is as indicated in Table 3:

Table 3. Structure of the Parent-Adolescent Communication Scale

\begin{tabular}{ccc}
\hline Subscales & Number of items & Item number \\
\hline Functional communication & 10 & $1,3,6,7,8,9,13,14,16,17$ \\
\hline Dysfunctional communication & 10 & $2,4,5,10,11,12,15,18,19,20$ \\
\hline Total & 20 & $1-20$ \\
\hline
\end{tabular}

\section{Design and Process}

This study adopted a pretest-posttest control group design to observe the effect of sandplay therapy for Korean-Chinese children living in China who experienced separation from their parents.

PACS was employed in a pretest-posttest design for the experimental group and the wait list control group. Sandplay therapy was provided for a period of three weeks, on January 3-23 in the year 2016. A total of 6 sessions were given to each participant every other day, with each session lasting 40 minutes. In addition, two parent-child interaction sessions-one before and one after sandplay therapy-were conducted so as to analyze the qualitative effect of sandplay therapy on parent-child communication. During interaction sessions, parents and children were placed in a room with a few games where they could naturally engage in play 
and dialogue for 30 minutes. After the entire program was completed, each parent and child individually had a 30-minute interview during which they shared their impressions of taking part in the program and reported the observed changes in parent-child communication. With the consent of all parents and children, all pretest and posttest sessions as well as sandplay therapy sessions were videotaped and sandpictures were photographed.

\section{Data Analysis}

Mann-Whitney U test and Wilcoxon signed rank test using SPSS 20.0 were conducted to analyze the quantitative data in both pretest and posttest. As for qualitative analysis, the study used the notes taken during parent-child interaction session held before and after sandplay therapy as well as the video footages of the entire program.

\section{Results and interpretations}

\section{The Effect of Sandplay Therapy on Parent-Child Communication}

To measure the effect of sandplay therapy on parent-child communication of Korean-Chinese children who experienced separation from their parents, the study examined the parent-child communication before and after sandplay therapy for the experimental group and the wait list control group. The effect of sandplay therapy on parent-child communication is outlined in Table 4:

As seen in Table 4, no significant differences could be found between the two groups in terms of their total pretest scores. Such result led to hypothesize that pre-test scores of the experimental group and the control group were homogeneous.

But when looking at the post-test result for each item of PACS, significant differences were observed in the functional communication, dysfunctional communication and the total score $(\mathrm{Z}=-2.52 *, \mathrm{p}<.05)$. Such result indicated that sandplay therapy enhanced functional 
Journal of Symbols \& Sandplay Therapy, Vol.7 No.2.

Table 4. A pretest-posttest comparison of parent-child communication

\begin{tabular}{|c|c|c|c|c|}
\hline & Group & $\begin{array}{l}\text { Pretest } \\
\text { M (SD) }\end{array}$ & $\begin{array}{l}\text { Posttest } \\
\text { M (SD) }\end{array}$ & $\mathrm{Z}$ \\
\hline \multirow{3}{*}{$\begin{array}{c}\text { Functional } \\
\text { communication }\end{array}$} & Experimental & $33.25(5.60)$ & $46.50(4.44)$ & $-2.52^{*}$ \\
\hline & Wait list control & $28.63(2.26)$ & $28.63(2.26)$ & .00 \\
\hline & $\mathrm{Z}$ & -2.53 & & \\
\hline \multirow{3}{*}{$\begin{array}{l}\text { Dysfunctional } \\
\text { communication }\end{array}$} & Experimental & $28.25(4.46)$ & $21.00(5.01)$ & $-2.53^{*}$ \\
\hline & Wait list control & $31.38(2.45)$ & $31.38(2.45)$ & .00 \\
\hline & $\mathrm{Z}$ & -3.38 & & \\
\hline \multirow{3}{*}{ Total } & Experimental & $61.50(2.62)$ & $67.50(4.28)$ & $-2.32^{*}$ \\
\hline & Wait list control & $60.00(3.12)$ & $60.00(5.01)$ & .00 \\
\hline & Z & -.91 & & \\
\hline
\end{tabular}

communication - which meant that the child does not feel repressed and can freely express his or her thoughts while communicating with the parent-and reduced dysfunctional communication. In other words, it can be said that sandplay therapy improved parent-child communication of Korean-Chinese children who experienced separation from their parents.

\section{Qualitative Changes in Parent-Child Communication after Sandplay Therapy}

This section discusses the result of a qualitative analysis on the changes in the interaction between parents and Korean-Chinese children who experienced separation from their parents. The analysis was done by videotaping the parent-child interaction session, writing down what had happened in each session, and extracting noteworthy information.

\section{1) Observed changes in parent-child communication}

Before sandplay therapy, Korean-Chinese children with an early separation experience were not willing to converse with their mothers, busy studying mothers' faces and expressions, and could not easily express their needs. After sandplay therapy, however, the children became 
Table 5. Observed changes in parent-child communication

Pretest
- (Silently watching his mother's behavior) Our
time.... (trailing off)
(Sighing when the mother just continues with
the game) All right... (Child A)
- (Flipping through the instructions) Looking at
the instructions... I think that's how it's done.
I don't know... That's what the instructions
say. (Child B)

- (Biting his fingernail) I wish mom would win the game.

(Giving the dice to the mother) It's your turn. We need to go in order. (Child C)

- (Studying his mother's face) What do you want to do $\cdots$ ?

Mom, how do you do this? (Studying his mother's face and fiddling with the instructions) (Child D)

- (Hesitantly) Is this $\cdots$ how it's done? I'm not sure $\cdots$ (Child E)

- (Looking at the instructions and studying his mother's face) Uhhh... We've been playing the wrong way.

(Studying his mother's face once she made a sullen face) I was just showing off. (Child F)

- I don't know what this means. How and what are we supposed to do? You honestly don't know as well, right mom? (Child G)

- Mom, don't you know how to do this? Never mind, just stop. You just gotta do it like this! (Child H)

\section{Posttest}

- (When the game collapsed) Let's do it again, do it again. You had a lot too, Mom. I think it's about to collapse. Oooh- (Moving his bottom up and down as if excited) (Child A)

- (Smiling when his eyes met with his mother's) I think this is the right way to do it. You take the money when. You get money when this is left. Once you make a full circle, you get 200,000 Korean won. (Child B)

- This game is about who rings the bell first. When you get five, you ring the bell. (Smiling delightfully as he explains the game to his mother) (Child C)

- You can start by putting it here at the center... (Looks at mom and then begins explaining the game rules) (Child D)

- (Becoming flustered as the mother raised her voice) Is this really where we do it? I think... (Child E)

- (Laughing awkwardly while listening to the mother's explanations) Is that how we're supposed to play? Haha, I had no idea. (Child F)

- (Looking at her mother face to face and smiling) Isn't this fun? You did it like this, so I am the winner. This is how it should be done. (Child G)

- Let's do rock-paper-scissors to decide who goes first. Mom, should we do something else? (Child $\mathrm{H})$ 
Journal of Symbols \& Sandplay Therapy, Vol.7 No.2.

Table 6. Perceived improvements in parent-child communication by the children

\begin{tabular}{|c|c|}
\hline Pretest & Posttest \\
\hline $\begin{array}{l}\text { - (Glancing at the mother) We barely talk even } \\
\text { at home } \cdots \text { She keeps on trying to scold me... } \\
\text { (Child A) } \\
\text { - It's just... Mom doesn't scold me. But it's like, } \\
\text { that I shouldn't be wrong. It's like that. So I } \\
\text { feel like I have to read the instructions well... } \\
\text { Something like that. (Child B) }\end{array}$ & $\begin{array}{l}\text { - I think I had more fun than I did last time. } \\
\text { This thing is about to fall } \cdots \text { and it's fun } \\
\text { playing with mom. (Child A) } \\
\text { - (Smiling slightly) The game was hard, but it } \\
\text { was better than I had thought since I was } \\
\text { playing with mom and we were thinking } \\
\text { together and everything. And it was fun. (Child } \\
\text { B) }\end{array}$ \\
\hline $\begin{array}{l}\text { - (Biting his fingernail) I wish mom would win. } \\
\text { There should be times when mom wins. I can } \\
\text { win when playing with my other friends. (Child } \\
\text { C) }\end{array}$ & $\begin{array}{l}\text { - Explaining to mom is fun. I like it better when } \\
\text { mom has fun, too. I'm excited. (Child C) }\end{array}$ \\
\hline $\begin{array}{l}\text { - It's okay when I talk to my older brother and } \\
\text { mom } \cdots \text { Mom and older brother tell me to do } \\
\text { it however I want it to } \cdots \text { They still tell me } \\
\text { kindly how it goes. (Child D) }\end{array}$ & $\begin{array}{l}\text { - I explain to them when I know thow to play } \\
\text { the game]. I, too, can do it } \cdots \text { Mommy and } \\
\text { older bro always just nags me... (Child D) }\end{array}$ \\
\hline $\begin{array}{l}\text { - When I talk to mom } \cdots \text { I am cautious } \cdots \\
\text { because I may say some things incorrectly. I } \\
\text { might get scolded for nothing } \cdots \text { (Child E) }\end{array}$ & $\begin{array}{l}\text { - I still feel scared when mom shouts... But I } \\
\text { know that she doesn't have a bad intention... } \\
\text { It's okay. (Child E) }\end{array}$ \\
\hline $\begin{array}{l}\text { - I'm scared 'cause I might get scolded, but”. } \\
\text { But I still fool around and play around a lot. } \\
\text { But E probably can't do that well 'cause she } \\
\text { gets scared. (Child F) }\end{array}$ & $\begin{array}{l}\text { - It seems that mom's trying to fix things... } \\
\text { Well, I should just be more careful too when } \\
\text { talking to mom, so I don't think it's bad... It } \\
\text { should gradually get better. (Child F) }\end{array}$ \\
\hline $\begin{array}{l}\text { - I really like mom, but sometimes she insists } \\
\text { that we do weird things. Sometimes she seems } \\
\text { to be listening, and then just digresses... So } \\
\text { sometimes I throw a fit. (Child G) }\end{array}$ & $\begin{array}{l}\text { - I like explaining things to mom and dad at } \\
\text { home, too. Mom listens well, and I'd like to } \\
\text { be smarter. (Child G) }\end{array}$ \\
\hline $\begin{array}{l}\text { - It's just } \cdots \text { You just gotta do it naturally, but } \\
\text { mom kept on saying that we gotta do } \\
\text { everything. It got me annoyed and frustrated. } \\
\text { (Child H) }\end{array}$ & $\begin{array}{l}\text { - It's fun to see mom working so hard [with the } \\
\text { games]. We didn't really play a lot together, } \\
\text { but we talked a lot and mom told me that } \\
\text { she'll play with me at home, too. I feel good. } \\
\text { (Child H) }\end{array}$ \\
\hline
\end{tabular}


more proactive-e.g., informing their mothers about the game rules, leading the play, and actively engaging in a conversation-and made efforts to understand their mothers. What appeared to be common among all participants was the act of waiting for the other person and reading the other person's emotions. It can be said that this was an expression of what they had experienced through sandplay therapy: the experience of having their emotions accepted by and empathized with others. Table 5 shows some of the key examples of changes in communication shown during parent-child interaction sessions:

\section{2) Perceived improvements in parent-child communication by the children}

During the individual interview, child participants complained that they feel extremely intimidated or scared when conversing with their mother. Parents reported that when they would raise their voice a bit or take a certain action, the children would become more intimidated than usual to the extent that they are even unable to say what they already know. But after sandplay therapy, parents reported that the children expressed a sense of intimacy, manifested the need to improve the parent-child communication, and showed positive changes. These changes can be interpreted to say that sandplay changed the way children perceived communication with their parents, that is, they began to notice improvements in the communication. Some of the key statements that indicates this change in awareness are listed in Table 6.

\section{Conclusion}

This study conducted sandplay therapy on Korean-Chinese children who experienced separation from their parents and analyzed the therapy's effect. A total of six sandplay sessions were employed for each children. Barnes and Olson's Parent-Adolescent Communication Scale (1982) was utilized to verify changes in the parent-child communication. A parent-child interaction session was conducted before and also after sandplay therapy for a qualitative analysis. After the entire program was completed, a one-on-one interview was held for each 
Journal of Symbols \& Sandplay Therapy, Vol.7 No.2.

parent and children.

A summary of the study's results is as follows:

First, Korean-Chinese children who experienced separation from their parents saw a significant improvement in their parent-child communication skills after sandplay therapy. A significant improvement was observed in each item of PACS: functional communication, dysfunctional communication, and the total score.

Second, a qualitative analysis on the parent-child communication of Korean-Chinese children who experienced separation from their parents found that sandplay therapy brought about changes in parent-child and also changed the way the children perceived the communication. As for post-sandplay therapy changes in the ways of communication, the child participants proactively informed their mothers about the game rules, actively engaged in a conversation, and made efforts to understand their mothers. In addition, the mothers and children waited for each other while playing games through careful observation and tried to reach each other's emotions. As for the changes in how the children perceived the communication, prior to sandplay therapy the child participants felt intimidated or scared during parent-child conversation and could not express their emotions and needs. But after therapy, these children felt intimacy with their mothers, felt less intimidated and afraid, and expressed their inner thoughts more frequently and freely than before.

These results lead to the conclusion that sandplay therapy can improve parent-child communication of Korean-Chinese children who experienced separation from their parents. When considering the effects of forceful parent-child separation on the growth and development of children, these results suggest that in the future there is a need to develop and implement more programs related to improving parent-child communication of Korean-Chinese children in China, who often experience early separation from parents due to various cultural, historical and economic circumstances and therefore are relatively less exposed to stable parent-child communication than other children. The results also indicate that these programs need to be conducted within an educational environment like schools-elementary, junior high and high schools alike-in consideration of the situations in Korean-Chinese communities in China.

Despite these limitations, this study is meaningful for the following reasons: First, it 
found that sandplay therapy greatly influences and helps improve parent-child relationship and communication of Korean-Chinese children who experienced separation from their parents. Second, there are not many existing studies involving psychotherapeutic approaches and counseling programs targeting Korean-Chinese children who experienced separation from their parents. Third, this study provided a helpful channel for the children to find their inner energy and strength.

\section{References}

Ahn, B. (2009). A study on the family separation of Korean Chinese following the super-national movement. The Korean Association of Northeast Asian Studies.

Barnes, H., \& Olson, D. H. (1982). Parent-adolescent communication scale. In D. H. Olsen. H. I. Mccubbin. H. Barnes. A. Larsen. M. Muxen \& M. Wilson (Eds.), Family Inventories (pp. 33-48). MN: Family Social Science, University of Minnesota.

Jeong, D. (2016). Effect of sandplay therapy on the behavior and parent-child relationship of Korean-Chinese children who experienced early separation. Master's thesis, Namseoul University.

Jeong, H., Kim, M., \& Lim, W. (2011). A study of the psychosocial characteristics of children of low income single parent families of Korean ethnicity in Chinese farming village. Korean Journal of Youth Studies, 18(1), 323-333.

Jo, B., \& Lee, J. (2005). Developmental environment and adjustment of Korean-Chinese children separated from both their parents. Korean Journal of Child Studies, 25(4), 231-245.

Kang, J. (2012). Diaspora and contemporary Yanbian Korean Chinese's imagined community: The social construction and reterritorialization of the ethinic community. Journal of Korean Sociological Association, 46(4), 96-146.

Kim, H. (2009). Work and life experiences of Korean-Chinese on visit work. Journal of Korean Cultural Anthropology, 42(2), 35-75.

Kim, M., Kim, S., Kim, D., \& Hur, C. (2012). The influence of social support on psychosocial adaptation of broken family Korean-Chinese children - The mediating effect of resilience. 
Journal of Symbols \& Sandplay Therapy, Vol.7 No.2.

Korean Journal of Comparative Education, 22(1), 99-119.

Kim, S. (2004). The path analysis among risk-protective factors on the resilience of cbildren from divorced families. Doctoral dissertation, Seoul Women's University.

Kim, Y. (1989). A study on the relationship between parent relationship, parent-child communication, family functions and adolescent cbild delinquency. Doctoral dissertation, Sookmyung Women's University.

Koo, J. (2011). The migration of Koreans in the era of globalization and transnational social space - by the example of Qingdao, China. Journal of Korean Studies Institute, 40, 421-457.

Korean Immigration Service (2015). www.immigration.go.kr.

Lee, C., \& Lee, H. (2004). A guidance on the education for students with one or no parent. China: Yanbian Education Press.

Lee, B., \& Jang, M. (2015). Comparisons between North Korean adolescent defectors and South Korean adolescents in expressions in sandplay therapy. Journal of Symbols \& Sandplay Therapy, 6(2), 31-45.

Lee, H. (2014). Cultural continuity and transfrom of Korean-Chinese families by examining transnational child-rearing practices. Joongangsiron, 39, 77-109

Lee, J. (2009). Impact of the self-differentiation and communication style of low-income single parents on children's problem behavior. Master's thesis, Soongsil University.

Lee, K., Lee, M., \& Kim, K. (2006). Interpersonal relationship and communication. Seoul: Hyunmoon.

Lee, S., \& Shahi, P. (2016). Image experiences in sandplay therapy in adolescents living in welfare facilities who suffered Nepal earthquake. Journal of Symbols \& Sandplay Therapy, 7(1), 81-96.

Park, H., \& Park, M. (2005). Cross-cultural differences in temperament among Korean-Chinese, Chinese in Yanji and Korean children. Journal of Korean Home Management Association, 43(3), $221-231$

Woo, M., \& Lee, N. (2013). Life course of "Joseonjok" (ethnic Korean in China) migrant women: Intersection of transnational temporality and spatiality. Journal of Korean Sociological Association, 47, 139-169. 
Chung, Da Un • Jang, Mikyung / Effects of Sandplay Therapy on Parent-Child Communication in Chinese-Korean Children Who Experienced Separation from Their Parents

Yoon, M., Jo, H., \& Park, S. (2012). The mediating effects of father attachment and mother attachment on the relationship of separation from their parents and school adjustment among Korean-Chinese adolescents. Journal of Adolescent Welfare, 14(1), 113-137.

Received : October 28, 2016

Revised : November 28, 2016

Accepted : December 1, 2016 